\title{
PARASCYTOLEPTUS AND SPONGIAXIUS REDEFINED WITH TWO NEW SPECIES FROM THE SOUTHWESTERN PACIFIC (DECAPODA, AXIIDEA, AXIIDAE)
}

\author{
BY \\ GARY C.B. POORE ${ }^{1}$ ) and DAVID J. COLLINS \\ Museum Victoria, GPO Box 666, Melbourne, Vic. 3001, Australia
}

\begin{abstract}
The axiid genera Parascytoleptus Sakai \& de Saint Laurent, 1989 and Spongiaxius Sakai $\&$ de Saint Laurent, 1989 are rediagnosed. Parascytoleptus papua from Papua New Guinea differs from the only other species in the genus, P. tridens, in the possession of three tubercles on the carapace, more prominent rostrum and an extremely elongated minor cheliped in the adult male. Spongiaxius holthuisi differs from S. novaezealandiae in having a shorter rostrum, more elongated propodus on the chelipeds, and shorter telson. It has no pleurobranchs as in the New Zealand species and possesses a non-articulating transverse suture on the uropodal exopod, absent in the New Zealand species.
\end{abstract}

\section{RÉSUMÉ}

Les diagnoses de deux genres d'Axiidae, Parascytoleptus Sakai \& de Saint Laurent, 1989 et Spongiaxius Sakai \& de Saint Laurent, 1989, sont révisées. Parascytoleptus papua de Papouasie Nouvelle-Guinée se distingue de la seule autre espèce du genre, $P$. tridens, par la présence de trois tubercules sur la carapace, d'un rostre plus proéminent et d'un petit chélipède extrêmement allongé chez le mâle adulte. Spongiaxius holthuisi diffère de $S$. novaezealandiae par un rostre plus court, un telson plus court, et un propode des chélipèdes plus allongé. Il est dépourvu de pleurobranchies comme l'espèce de Nouvelle Zélande, mais possède une suture transverse non articulée sur l'exopodite des uropodes qui est absente chez l'espèce de Nouvelle Zélande.

\section{INTRODUCTION}

The fauna of sponge lobsters (Axiidae) of the southwestern Pacific is rich in species (Lin, 2006; Poore \& Collins, 2009 and references therein; Sakai

\footnotetext{
1) e-mail: gpoore@museum.vic.gov.au 
$\&$ de Saint Laurent, 1989). Here we describe two more species and take the opportunity to redefine their respective genera after looking at related species. The first was collected during an expedition by the Museum and Art Gallery of the Northern Territory, Darwin, to Papua New Guinea. The second derives from collections made in New Caledonia (Richer de Forges, 1991). Callianassid and upogebiid shrimps from the latter were described by NgocHo (1991).

Material is deposited in the Museum and Art Gallery of the Northern Territory, Darwin (NTMAG), Museum Victoria, Melbourne (NMV), and Muséum national d'Histoire naturelle, Paris (MNHN). Measurements are of carapace length including rostrum (cl.) and total length (tl.). Illustrations were made by the second author and prepared for publication using Adobe Illustrator and many of the recommendations of Coleman (2003).

\section{TAXONOMIC ACCOUNT}

Family AxIIDAE Huxley, 1879

Remarks. - The family was recently rediagnosed (Poore \& Collins, 2009) to include smaller specialised taxa previously included in other families, Calocarididae Ortmann, 1891 and Eiconaxiidae Sakai \& Ohta, 2005.

Parascytoleptus Sakai \& de Saint Laurent, 1989

Parascytoleptus Sakai \& de Saint Laurent, 1989: 39.

Type species. - Paraxius tridens Rathbun, 1906, by original designation.

Diagnosis. - Carapace smooth; cervical groove visible laterally over third distance to anterolateral margin. Rostrum triangular, broad, laterally smooth or obscurely denticulate, about as long as eyestalks, slightly depressed below level of carapace, not continuous with lateral carinae; supraocular spines prominent; lateral carinae visible only at base of supraocular spine; submedian carina absent or evident only as blunt anterior tooth; median carina absent or weak, without or with 1 blunt tubercle, unbifurcated posteriorly; postcervical carina absent. Abdominal somite 1 pleuron rounded; pleuron 2 broad, anteriorly rounded, ventrally flat, posteriorly rounded; pleura 3-5 posteriorly rounded. Eyestalk cylindrical, articulating; cornea pigmented. Antenna article 2 without distal spine, scaphocerite absent or reduced. Maxilliped 3 exopod not clearly bent at base of flagellum. Pleurobranchs present above pereopods 
2-4; podobranchs and arthrobranchs well developed; epipods present on maxilliped 2 to pereopod 4 . Pereopods 1 decidedly asymmetrical, with propodus cylindrical; carpus-dactylus upper and lower margins unarmed. Pereopods 35 propodi with transverse rows of few robust setae; dactyli 3 and 4 tapering, with 2 longitudinal rows of robust setae; dactylus 5 tapering, with 1 robust seta. Pleopods 3-5, appendix interna present. Pleopod 1 of male absent. Pleopod 2 of male with appendix interna, without appendix masculina. Uropodal exopod without transverse suture. Telson with lateral fixed spines and posterolateral robust setae; apex rounded.

Remarks. - Sakai \& de Saint Laurent (1989) stated that their new genus shared with Scytoleptus Gerstäcker, 1856 a depressed rostrum, short cervical groove, long antenna article 4, unequal first pereopods, pereopod 3 with conspicuous transverse rows of robust setae, pleurobranchs above pereopods $2-4$, telson with a pair of posterolateral robust setae, and rounded pereopodal epipods. They did not mention the absence of a uropodal exopod suture. The two genera, both then monotypic, were differentiated using the rostrum and gastric carinae, and telson. Some of these characters are not convincing at a generic level but others are. While Parascytoleptus lacks a male pleopod 1 and an appendix masculina. Scytoleptus serripes Gerstäcker, 1856 possesses a well developed setose pleopod 1, obvious appendix masculina and has a unusually elevated gastric region such that the front is almost vertical between the rostrum and posterior tubercle on the median carina.

Sakai \& de Saint Laurent (1989) stated that while $S$. serripes possessed an arthrobranch on maxilliped $2 P$. tridens does not (an observation doubted by M. de Saint Laurent, pers. comm., 1990). We can confirm its presence in both species after examination of a specimen of $P$. tridens from New Caledonia (see below).

The type species, Parascytoleptus tridens (Rathbun, 1906) was described from the French Frigate Shoals and Modu Manu, Hawaii, at 30-60 m depth. A type specimen was redescribed by Sakai \& de Saint Laurent (1989: 4041, fig. 10). The species is said to occur also in Madagascar (Sakai \& de Saint Laurent, 1989), Moorea and Bora Bora, French Polynesia (Sakai, 1992), Aldabra Atoll (Kensley, 1994, 2003) and to be "the commonest axiid in reef habitats around Guam" (Kensley, 2003). Kensley believed the species to be probably widespread in coral rubble habitats throughout the Indo-West Pacific. Sakai's (1992: 212-215, fig. 2) illustration of a male from Moorea with a more acute rostrum than the type from Hawaii suggests that more than one species may be involved although this variation could admittedly be within expected 
variation. The description here of a new species from Papua New Guinea with more obvious specific differences raises questions about the identity of reports (outside Hawaii) of $P$. tridens throughout the Indo-West Pacific.

\title{
Parascytoleptus papua n. sp.
}

\author{
(figs. 1, 2)
}

Material examined. - Holotype. Papua New Guinea, Madang, between Pik and Kranket islands, $05^{\circ} 09.6^{\prime} \mathrm{S} 145^{\circ} 49.7^{\prime} \mathrm{E}, 3-8 \mathrm{~m}$, R. Hanley, 21 Oct. 1991, NTMAG Cr010213 (male, cl. $4.2 \mathrm{~mm}$, tl. $10.3 \mathrm{~mm}$ ). Paratypes. Collected with holotype, NTMAG Cr016887 (juvenile, cl. $2.5 \mathrm{~mm}$, tl. $5.7 \mathrm{~mm}$ ); NTMAG Cr010105 (female, cl. $2.6 \mathrm{~mm}$, tl. $6.1 \mathrm{~mm}$ ).

Comparative material of $P$. aff. tridens. - New Caledonia, MNHN Th1153 (ovigerous female, cl. $7.3 \mathrm{~mm}$, tl. $20.7 \mathrm{~mm}$ ).

Description of male holotype. - Carapace smooth. Rostrum 0.25 times length of front-to-cervical groove, broadly triangular, with 1 or 2 lateral tubercles anterior to supraocular spine, slightly depressed below level of median carina, anteriorly directed, continuous with obsolete lateral carinae. Supraocular spines prominent, broadly triangular. Lateral carina obsolete. Submedian gastric carina evident only as 1 blunt tooth. Median carina obsolete, with 1 tooth, sloping down at $30^{\circ}$ in front of tooth. Abdominal somite 1 pleuron ventrally rounded; pleuron 2 asymmetrical, posteriorly rounded; pleura 3-5 rounded; pleura 6 rounded.

Eyestalk, just exceeding rostrum; cornea pigmented. Antennular peduncle reaching to midpoint of antennal article 4; article 1 unarmed, antennal gland on prominent tubercle. Antennal article 1 unarmed; article 2 unarmed; scaphocerite absent; article 4, 1.8 times length of article 2; article 5 about half length of article 4. Maxilliped 3 coxa unarmed; basis lower margin with 1 spine; ischium unarmed; merus with 2 spines; crista dentata of about 12 teeth; carpus unarmed.

Pereopods 1 assumed asymmetrical. Major cheliped missing.

Minor cheliped elongate, 2.6 times carapace length; coxa-carpus unarmed; merus upper margin convex, lower margin concave, unarmed; propodus downcurved, upper margin 1.5 times carpus length; fixed finger as long as upper palm, cutting edge smooth; dactylus evenly curved and tapering.

Pereopod 2 ischium lower margin unarmed; merus lower margin unarmed; carpus as long as chela; propodus upper margin as long as dactylus. Pereopod 3 merus unarmed; propodus 2.0 times as long as dactylus, with 4 transverse rows each of 2-4 robust setae; dactylus tapering, with 2 large robust setae plus longitudinal row of 8 smaller robust setae on inner face, plus unguis. Pereopod 4 propodus 2.3 times as long as dactylus, distally densely setose, 


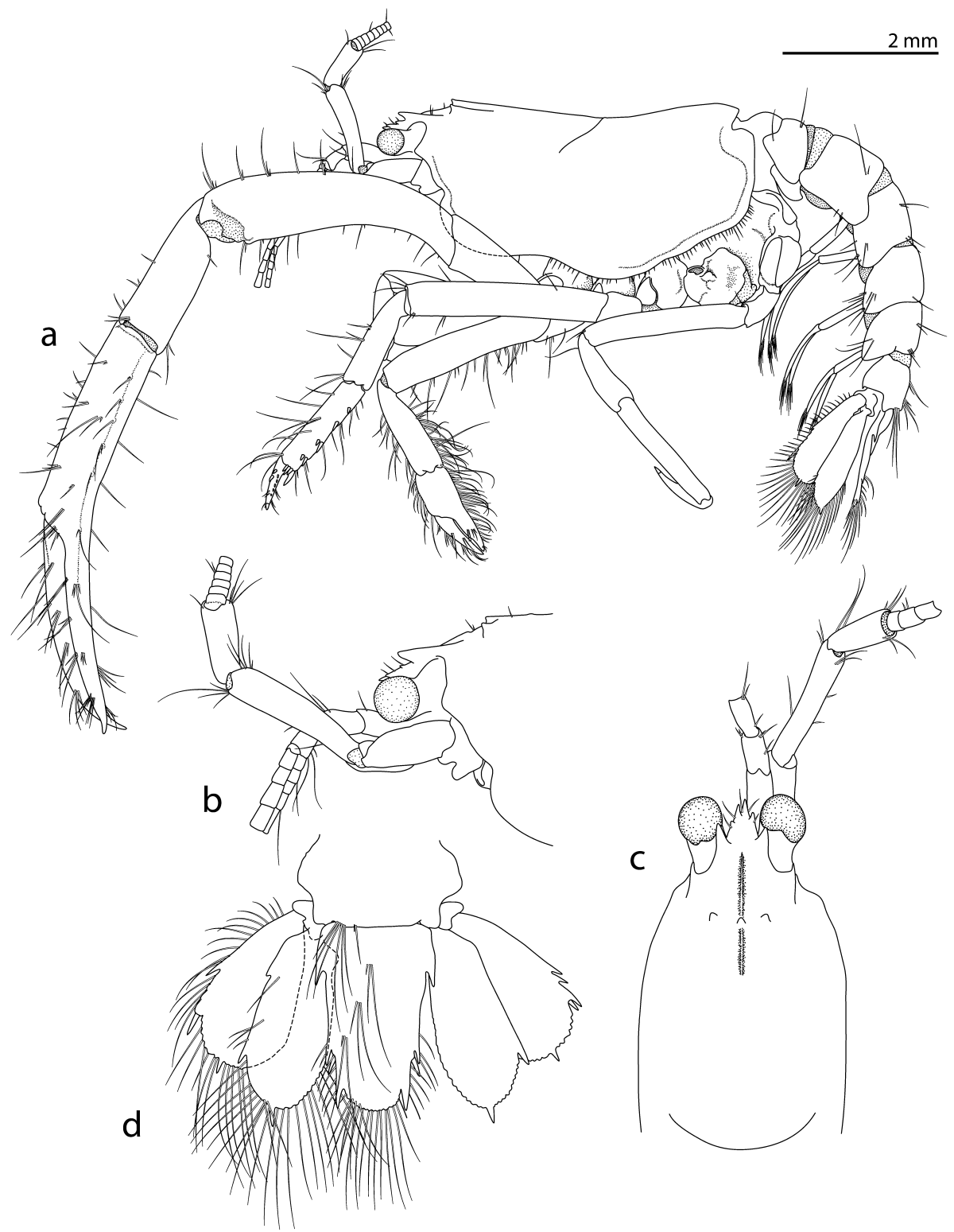

Fig. 1. Parascytoleptus papua new species, holotype. a, habitus; b, c, anterior carapace, antennules and antennae; $\mathrm{d}$, telson and uropods.

with 5 transverse rows each of 1-5 robust setae; dactylus tapering, with 3 large robust setae plus longitudinal row of 8 smaller robust setae on inner face, plus unguis. Pereopod 5 propodus 2.3 times as long as dactylus, not subchelate, 


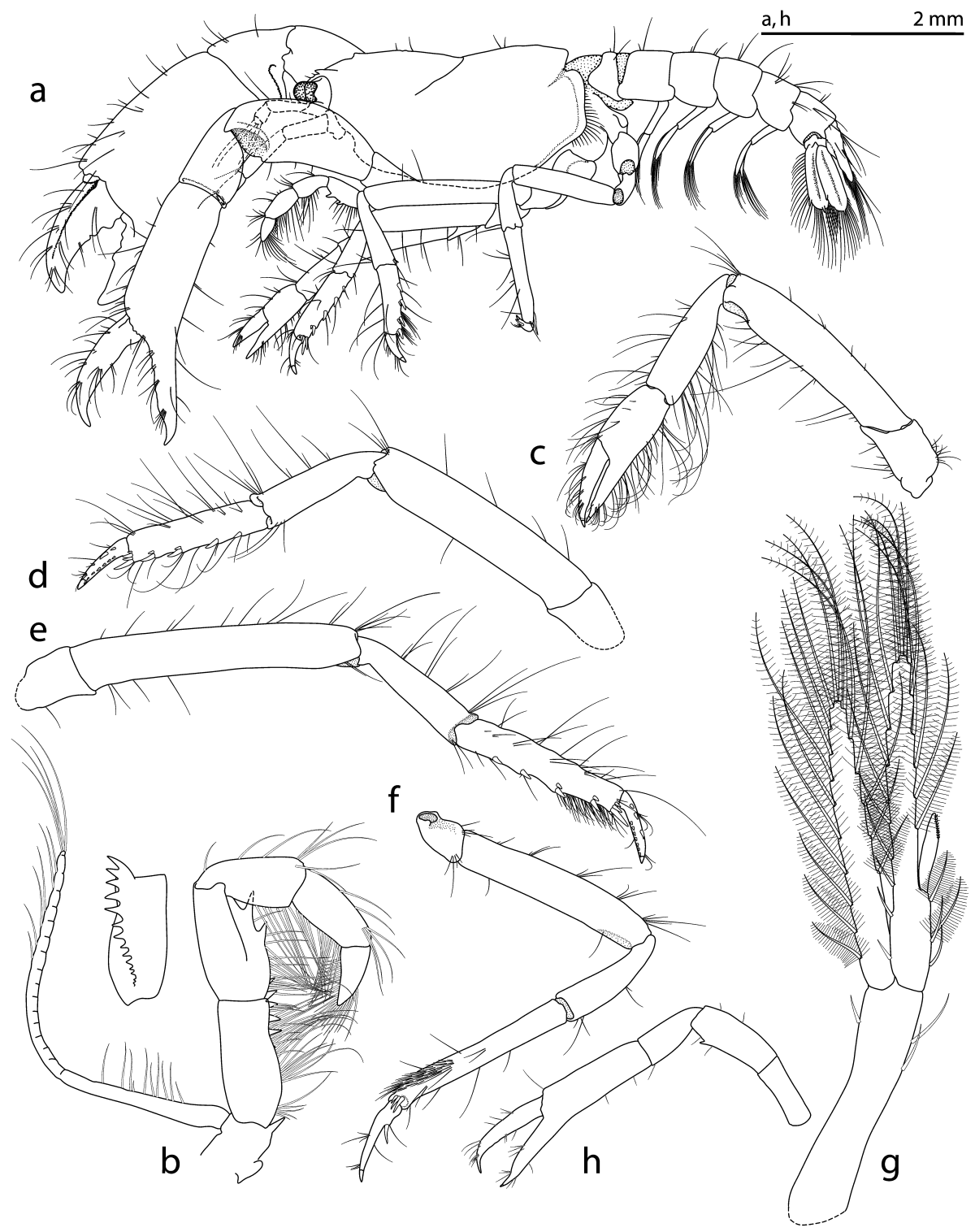

Fig. 2. Parascytoleptus papua new species. Paratype female, cl. $4.2 \mathrm{~mm}$ : a, habitus. Holotype: $\mathrm{b}$, maxilliped 3 with detail of crista dentata on merus; c-f, pereopods 2-5; g, pleopod 2. Paratype juvenile, cl. $2.6 \mathrm{~mm}: \mathrm{h}$, minor cheliped.

distally densely setose, with distal transverse row of 3 robust setae; dactylus tapering, with 1 robust seta mesially, plus unguis.

Pleopod 1 absent. Pleopods 2-5 each with appendix interna 0.2 length of endopod. Pleopod 2 without appendix masculina. 
Telson 1.6 times as long as wide, widest proximally, then tapering to 0.6 greatest width, lateral margin with 3 strong spines, second accompanied by 1 robust seta, distal margin convex between distolateral spines, without posteromedian spine; dorsal face without oblique ridges or spines. Uropodal endopod 2.2 times as long as wide, lateral margin without or with 1 lateral spine, with strong distolateral spine, longitudinal ridge with distal spine. Uropodal exopod 1.8 times as long as wide, lateral margin with 1 or 2 spines, posterolateral angle with 1 spine and 1 robust seta, longitudinal rib with 1 distal marginal spine.

Female, cl. $2.6 \mathrm{~mm}$. Rostrum acutely triangular, without lateral teeth. Maxilliped 3 merus with 1 spine. Pereopods 1 asymmetrical, of similar lengths. Major cheliped 2.5 times as long as carapace length; coxa to ischium unarmed; merus upper margin convex, unarmed, lower margin with 1 small spine; carpus unarmed; propodus unarmed; fixed finger 0.5 times as long as upper palm, cutting edge with 1 blunt tooth; dactylus distally curved, cutting edge unevenly toothed. Minor cheliped twice carapace length; coxa-carpus unarmed; merus lower margin barely concave, with 1 small spine; propodus down-curved, upper margin 1.5 times carpus length; fixed finger 0.8 length of upper palm, cutting edge smooth; dactylus evenly curved and tapering.

Juvenile, cl. $2.5 \mathrm{~mm}$ (without visible gonopores). Rostrum acutely triangular, with 1 lateral tooth on one side. Supraocular spine and gastric tubercles sharper than in male or female. Maxilliped 3 merus with 1 spine. Major cheliped merus with 1 tooth on lower margin; fixed finger with 4 blunt proximal teeth on cutting edge. Minor cheliped as long as major; merus with 1 tooth on lower margin.

Etymology. - From Papua New Guinea (noun in apposition).

Distribution. - Papua New Guinea, Madang; 3-8 m depth.

Remarks. - The new species is represented by a male, female and juvenile which differ in the relative size and spination of the chelipeds, and the degree of armature of the rostrum, carapace, maxilliped 3 and uropods. The male holotype in particular has an elongated minor cheliped; its major cheliped is missing, presumed swollen like that of the other specimens. Parascytoleptus papua differs from $P$. tridens in the possession of three tubercles on the carapace, one median and two submedian; none are reported for the type species or could be seen in the specimen at hand. The rostrum is more prominent than in $P$. tridens and usually laterally tuberculate. The telson of P. papua is longer and not as tapered as in Rathbun's (1906) or Sakai \& de Saint Laurent's (1989) figures of $P$. tridens. The telson is 1.4 times as long as 
wide in the latter and in the female from New Caledonia. The minor cheliped would appear to become extremely elongated in the adult male, much more so than in the female and juvenile, and than that of the male of what Sakai (1992) called P. tridens from Tahiti. Rathbun's (1906) figure of a female minor cheliped and that of the New Caledonia female are more robust than in the female of the new species but possess more delicate fingers.

\section{Spongiaxius Sakai \& de Saint Laurent, 1989}

Spongiaxius Sakai \& de Saint Laurent, 1989: 41; Poore, 1994: 97 (key); Sakai \& Ohta, 2005: 88.

Sakaiocaris Kensley, 1989: 964-965 (objective synonym, same type species).

Type species. - Axiopsis brucei Sakai, 1986, by original designation.

Diagnosis. - Carapace smooth; cervical groove visible laterally over most of distance to anterolateral margin. Rostrum triangular, dorsally deeply furrowed, extending beyond eyestalks, slightly depressed below level of carapace, well separated from lateral carinae, laterally armed with erect evenly-spaced spines; supraocular spines absent; lateral carina spinose; submedian carina present, spinose; median carina a spinose ridge; postcervical carina absent. Abdominal somite 1 pleuron acute; pleura 2-5 asymmetrical, posteroventrally acute. Eyestalk cylindrical, articulating; cornea pigmented. Antenna, scaphocerite prominent, curved apically downwards; distal spine on antenna article 2 straight, acute. Maxilliped 3 exopod not clearly bent at base of flagellum. Pleurobranchs absent or present above pereopods 2-4; podobranchs and arthrobranchs well developed; epipods present on maxilliped 2 to pereopod 4. Pereopods 1 asymmetrical, propodus cylindrical, weakly tuberculate; carpusdactylus upper and lower margins carinate. Pereopod 2 chela strongly pubescent. Pereopods 3-5 propodi with transverse rows of multiple robust setae; dactyli tapering, with clusters of robust setae. Pleopods 3-5, appendix interna present. Pleopod 1 of male present or absent. Pleopod 2 of male with appendix masculina and appendix interna. Uropodal exopod with non-articulating transverse suture or without. Telson with lateral fixed spines and posterolateral robust setae; apex rounded, with medial spine.

Remarks. - Sakai \& Ohta (2005) and Richer de Forges et al. (2009) published colour photos of specimens of the type species, Spongiaxius brucei, from the Philippines showing it to be bright orange-red. The species ranges from here to the Northern Territory and Western Australia where it is well represented in collections. Besides the type species, Sakai \& de Saint Laurent (1989) listed Axius (Neaxius) odontorhynchus De Man, 1905, Axius (Axius) 
novaezealandiae Borradaile, 1916 and Axius (Axiopsis) pitatucensis De Man, 1925. Axius odontorhynchus was transferred to Platyaxius Sakai, 1994 by Poore \& Collins, 2009. Axius pitatucensis has few but strong rostral and gastric carinal spines and does not belong to Spongiaxius (de Saint Laurent, pers. comm. to GCBP, 1990) and was not listed by Sakai \& Ohta (2005).

The pleurobranchs and male pleopod 1 vary between the three remaining species, present in some, absent in others. Sakai \& de Saint Laurent (1989) noted, and we can confirm, the presence of pleurobranchs in S. brucei (overlooked by Sakai, 1986). They reported pleurobranchs in S. novaezealandiae but we found none in the similar species described below. The male pleopod 1 of $S$. brucei has a triangular typically-axiid article 2 but that of the new species is simple and tapering while it is absent in males of all sizes of S. novaezealandiae. The suture across the uropodal exopod is weakly articulating in S. brucei, barely visible and not articulating in the new species described below, but is not visible at all in $S$. novaezealandiae. We examined a syntype of Axius novaezealandiae held at MNHN (see below) and S. Ahyong examined a range of specimens of S. novaezealandiae held at NIWA. Sakai \& de Saint Laurent's (1989) observations were confirmed.

\section{Spongiaxius holthuisi n. sp.}

$$
\text { (figs. 3-5) }
$$

Material examined. - Holotype. New Caledonia, Grand Récif Sud, $22^{\circ} 30^{\prime} \mathrm{S} 167^{\circ} 12^{\prime} \mathrm{E}$, 60 m, "blocs et coraux", B. Richer de Forges, ORSTOM stn 380, 22 Jan. 1985, MHNH Th1032 (male, cl. $9.2 \mathrm{~mm}$, tl. $26 \mathrm{~mm}$ ). Paratypes. Collected with holotype, NMV J34095 (2 ovigerous females, cl. $8.5 \mathrm{~mm}$ ). Grand Récif Sud, New Caledonia, 22 $46^{\prime} \mathrm{S} 167^{\circ} 4^{\prime} \mathrm{E}, 284 \mathrm{~m}, 23 \mathrm{Jan} .1985$ (ORSTOM stn 397bis), Th1031 (male, cl. $7.7 \mathrm{~mm}$ ). New Caledonia, $22^{\circ} 46^{\prime} \mathrm{S} 167^{\circ} 20^{\prime} \mathrm{E}, 300 \mathrm{~m}$, 30 Sep. 1885 (MUSORSTOM IV stn 227), Th1024 (male cl. $8 \mathrm{~mm}$ ); $22^{\circ} 51.3^{\prime} \mathrm{S} 167^{\circ} 12^{\prime} \mathrm{E}$, 405-430 m, 28 Sep. 1985 (MUSORSTOM IV stn 213), Th1021 (4 males, cl. 7.0-7.5 mm); $22^{\circ} 53.8^{\prime} \mathrm{S} 167^{\circ} 13.9^{\prime} \mathrm{E}, 425-440 \mathrm{~m}, 28$. Sep. 1985 (MUSORSTOM IV stn 214), NMV J60840 (ovigerous female, cl. $9 \mathrm{~mm} ; 2$ males, cl. $6 \mathrm{~mm}$ ); $22^{\circ} 57.6^{\prime} \mathrm{S} 167^{\circ} 33^{\prime} \mathrm{E}, 410-440 \mathrm{~m}$, $30 \mathrm{Sep}$. 1985 (MUSORSTOM IV stn 222), Th1022 (2 ovigerous females, cl. 8.3, $9.5 \mathrm{~mm}$ ).

Other material. - Numerous specimens (38 females, mostly ovigerous, cl. $4.3-10 \mathrm{~mm} ; 35$ males, cl. 5-9 mm) in 20 lots at MNHN from region of New Caledonia, Île des Pins, Îles Loyautés, Chesterfield-Bellona Plateau, Norfolk Ridge, $19-25^{\circ} \mathrm{S}, 230-600 \mathrm{~m}$ depth.

Comparative material. - Axius novaezealandiae Borradaile, 1916: New Zealand, Terra Nova stn 16, MNHN Th940 (syntype donated by Natural History Museum, London, male, cl. $\sim 20 \mathrm{~mm}$, rostrum broken).

Description of male holotype. - Carapace smooth. Rostrum 0.35 times length of front-to-cervical groove, triangular, lateral margin with 5 erect curved spines, apex with 1 erect spine. Supraocular spines absent. Lateral carina with 6 triangular teeth, diminishing posteriorly. Submedian carina with 7 teeth, 


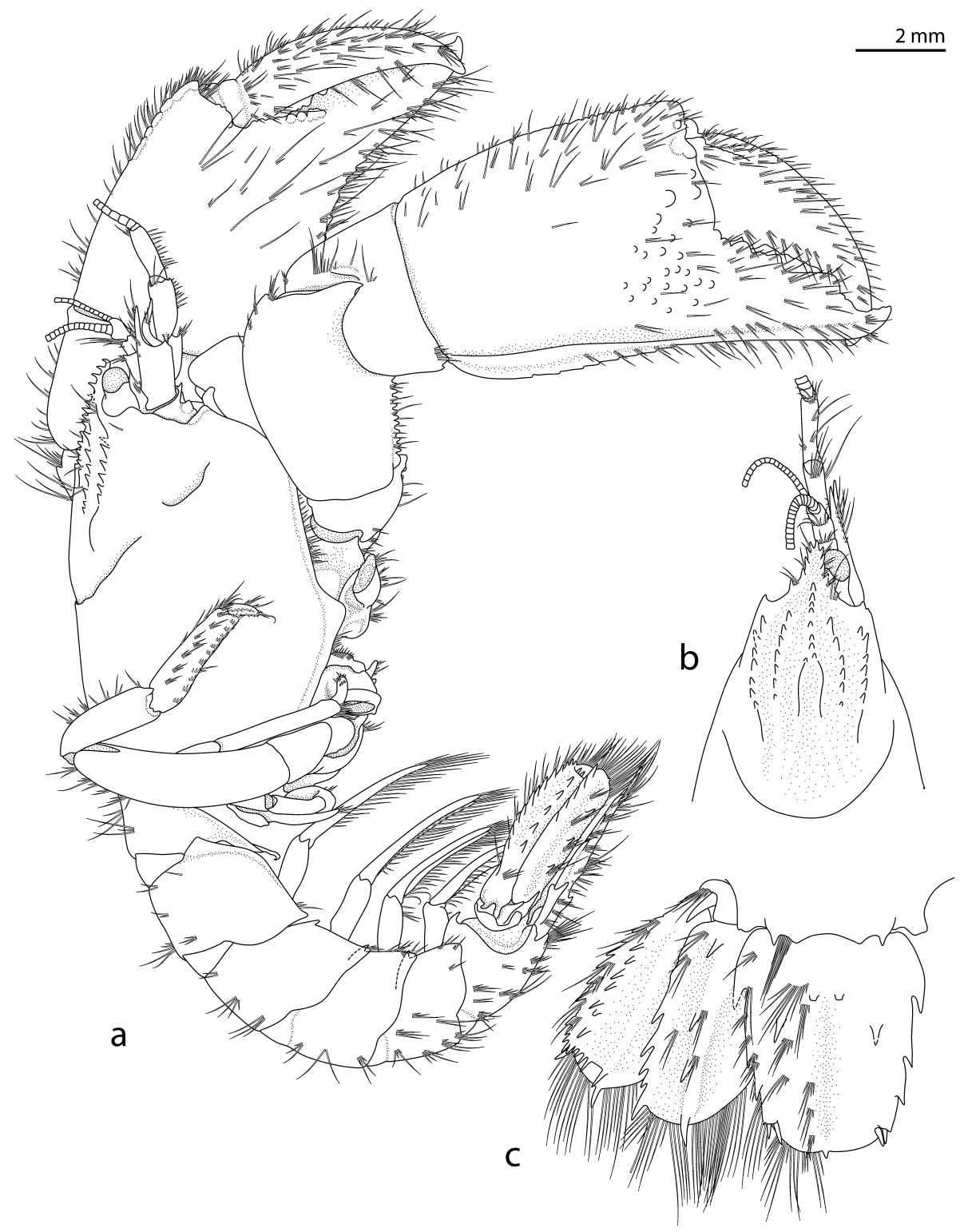

Fig. 3. Spongiaxius holthuisi new species, holotype. a, habitus; $b$, anterior carapace, antennules and antennae; c, telson and left uropod.

diminishing posteriorly. Median carina with 9 spines diminishing posteriorly, bifurcating posteriorly. Pleurobranchs absent. Abdominal pleuron 1 ventrally acute and narrow; pleuron 2 broad, asymmetrical, anteriorly angled, ventrally 


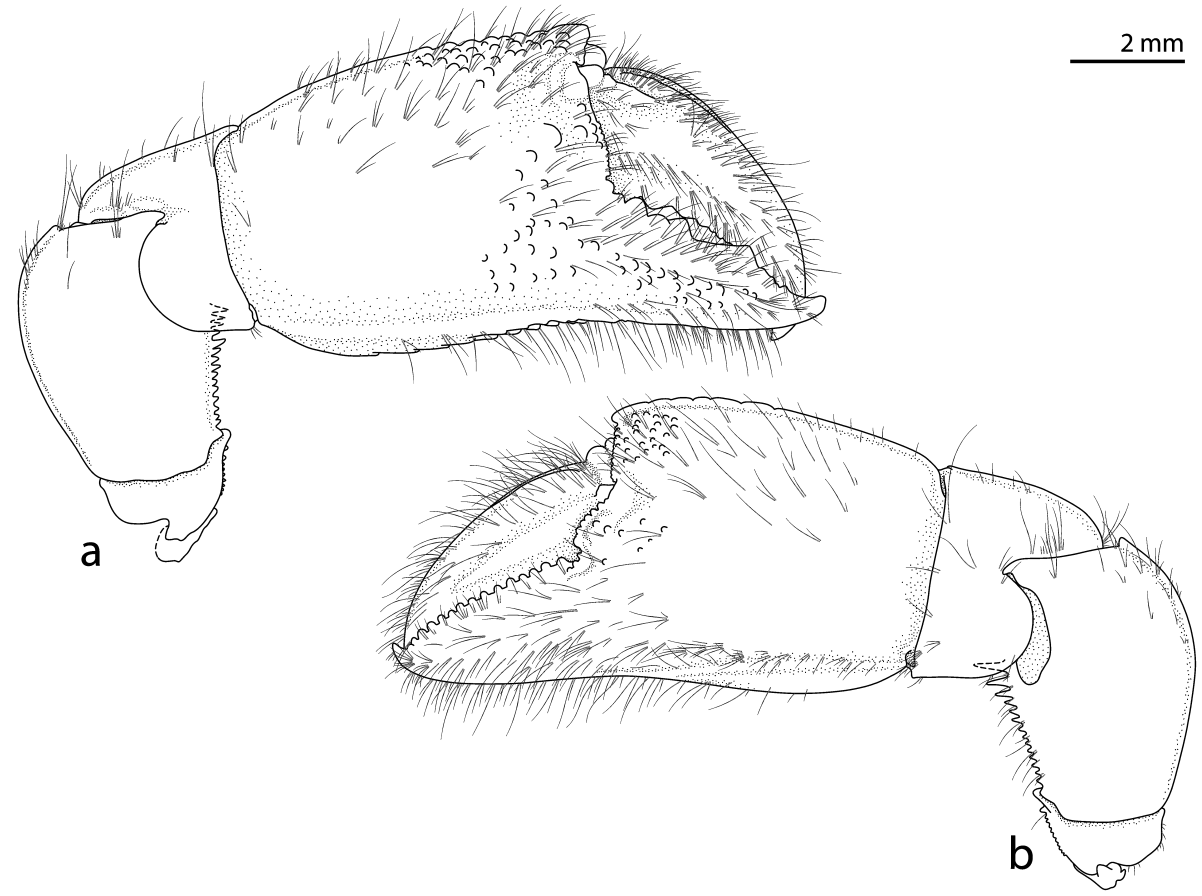

Fig. 4. Spongiaxius holthuisi new species, holotype. a, b, major (right) and minor (left) chelipeds.

flat, posteroventrally acute; pleura 3-5 asymmetrical, angled posteriorly, with anterovental tooth; pleuron 6 with ventral tooth.

Eyestalk slightly shorter than rostrum; cornea pigmented. Antennular peduncle reaching to midpoint of antennal article 4. Antennal article 1 with 1 ventral spine and 2 small tubercles; article 2 with prominent distal spine; scaphocerite strongly curved downwards, extending beyond distal spine of antennal article 2; article 3 with small distal spine; articles 4 and 5 each approximately as long as article 2 excluding distal spine. Maxilliped 3 coxa, basis and ischium lower margins each unarmed; crista dentata of approximately 40 small teeth; merus with 3 spines; carpus unarmed.

Pereopods 1 scarcely differentiated, major 1.1 times length of minor, slightly more swollen than minor. Major pereopod 1 (right) ischium lower margin with about 9 tubercles becoming larger distally; merus lower margin with 15 erect spines, larger distally, upper margin convex, carinate; carpus unarmed, upper magin carinate; propodus lower lateral margin carinate, upper margin twice as long as carpus, carinate with low tubercles on distal half, lateral face with low tubercles distally and extending onto fixed finger, mesial 


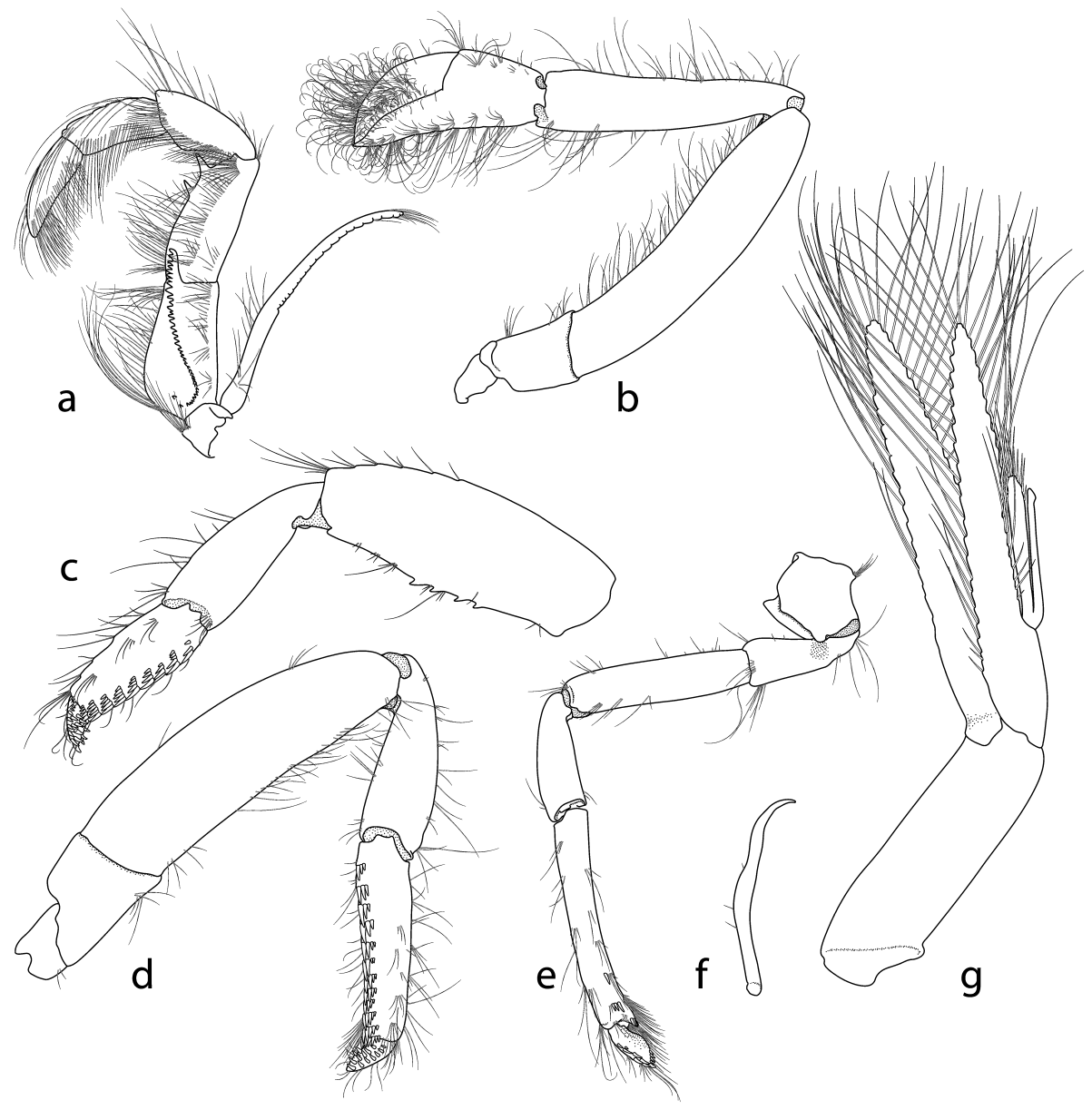

Fig. 5. Spongiaxius holthuisi new species, holotype. a, maxilliped 3; b-e, pereopods 2-5; f, g pleopods 1, 2 (male).

face with low tubercles especially along lower margin; fixed finger 0.5 times length of propodus upper margin, setose, cutting edge with few low teeth, largest at two-thirds; dactylus unarmed, setose, upper margin convex, carinate, cutting edge with obsolete teeth.

Minor cheliped ischium lower margin with about 10 tubercles becoming larger distally; merus lower margin with 14 spines, upper margin slightly convex, carinate; carpus unarmed, upper margin carinate; propodus lower lateral margin carinate, upper margin carinate with small tubercles distally; fixed finger with about 15 small evenly spaced rounded teeth; dactylus unarmed, setose, upper margin convex, carinate, cutting edge smooth. 
Pereopod 2 unarmed; carpus 1.3 times length of chela; chela strongly pubescent; dactylus curved, 1.2 times as long as propodus upper margin. Pereopod 3 merus robust, lower margin with 4 spines; carpus unarmed; propodus with 9 clusters of 4 or 5 robust setae on lower margin, 3.5 times as long as dactylus; dactylus with 3 rows of 4 or 5 robust setae on inner face. Pereopod 4 merus robust, unarmed; carpus unarmed; propodus lower margin with 12 clusters of 4 or 5 robust setae, 4.5 times as long as dactylus; dactylus with 2 rows of 6 or 7 robust setae on inner face. Pereopod 5 slender, subchelate; propodus 4.3 times length of dactlylus, lower margin with 3 clusters of setae on proximal half; dactylus with 2 marginal longitudinal rows of about 7 robust setae.

Pleopod 1 of male uniramous, tapering. Pleopod 2 appendix interna 0.3 times length of endopod; appendix interna scarcely longer than appendix interna.

Telson 1.7 times as long as wide, widest proximally, lateral margin with 3 spines, posterolateral angle with 2 robust setae, distal margin slightly convex with medial spine; dorsal face with median furrow, 2 spines in each oblique row. Uropodal endopod 1.9 times as long as wide, with 5 lateral spines and 1 distolateral spine, longitudinal ridge with 4 spines. Uropodal exopod 2.3 times as long as wide, with about 14 lateral spines, 2 longitudinal ribs (outer rib with 7 spines); transverse suture with 6 spines ( 2 at posterolateral angle, 3 sublateral, 1 on longitudinal rib); article 2 with 1 distal marginal spine.

Variation. - The numbers of spines vary between individuals and from one side of the animal to another. In the largest male, the rostrum may carry as many as seven spines on each side, the lateral carina with six or seven teeth, the submedian carina with up to ten teeth and the median carina with ten or eleven spines.

Etymology. — For Lipke Bijdeley Holthuis, 1921-2008, in appreciation of his long and valuable contribution to carcinology and of his advice to the first author.

Distribution. - New Caledonia and surrounding shelf and slope, $19-25^{\circ} \mathrm{S}$; 60-600 m depth.

Remarks. - Apart from sexual characters, the ovigerous female paratypes differ only slightly from the holotype. Males and females are of similar sizes. Females are ovigerous from a small size (cl. 4.3-10 mm). The new species is most similar to S. novaezealandiae (Borradaile, 1916) from northern New Zealand reillustrated in part by Sakai \& de Saint Laurent (1989: 42-43, fig. 11). Spongiaxius holthuisi differs in having a shorter rostrum, more elongated 
propodus on the chelipeds, and shorter telson. Spongiaxius novaezealandiae has three pleurobranchs but none are present on the new species. The New Zealand species lacks a transverse suture on the uropodal endopod while a faint suture is present in the new species. At $27 \mathrm{~mm}$ long, the new species is only half the size of the New Zealand species. Balss (1933) illustrated the telson and uropod of $S$. novaezealandiae but showed the telson to be shorter than in any other report. The telson is broader in the male syntype at MNHN (1.5 times as long as broad) than in the new species.

Several of the collections were taken from a sponge, one with 35 specimens. In a second sponge sample the species co-occurred with another as yet undescribed species of Spongiaxius.

\section{ACKNOWLEDGEMENTS}

This paper is dedicated to the memory of Lipke Bijdeley Holthuis and his contribution to the taxonomy of thalassinidean (now axiidean) lobsters and Crustacea generally. We thank Suzanne Horner, NTMAG, Darwin, for the loan and donation of the material studied in this contribution. We appreciate the hospitality of Nguyen Ngoc-Ho and Régis Cleva, MNHN, Paris, who made specimens available. We thank Shane Ahyong, National Institute of Water and Atmosphere, Wellington, New Zealand, for examining specimens on our behalf. Spongiaxius holthuisi is one of several similar species of Spongiaxius from the Indo-West Pacific recognised by the late Michèle de Saint Laurent in the 1980s. We thank her for making our task so much easier.

\section{REFERENCES}

BALSs, H., 1933. Ueber einige systematisch interessante indopazifische Dekapoden. Mitteilungen aus dem Zoologischen Museum in Berlin, 19: 85-98.

Borradaile, L.A., 1916. Crustacea. Part I. Decapoda. British Antarctic ('Terra Nova') Expedition, 1910, Natural History Reports (Zoology), 3: 75-110.

Coleman, C.O., 2003. "Digital inking": how to make perfect line drawings on computers. Organisms, Diversity and Evolution, 3: Electronic supplement, 14: 1-14.

DE MAN, J.G., 1905. Diagnoses of new species of macrurous decapod Crustacea from the "Siboga-Expedition". Tijdschrift der Nederlansche Dierkundige Vereeniging, 9: 587-614.

— —, 1925. Ueber neue oder wenig bekannte Axiidae. Mitteilungen aus dem Zoologischen Museum in Berlin, 12: 117-140.

GerstäCKER, A., 1856. Carcinologische Beiträge. Archiv für Naturgeschichte, 22: 101-162.

HUXLEY, T.H., 1879. On the classification and the distribution of the crayfishes. Proceedings of the Zoological Society of London, 1878: 752-788. 
Kensley, B., 1989. New genera in the thalassinidean families Calocarididae and Axiidae (Crustacea: Decapoda). Proceedings of the Biological Society of Washington, 102: 960967.

- - 1994. The genus Coralaxius redefined, with descriptions of two new species (Crustacea: Decapoda: Axiidae). Journal of Natural History, 28: 813-828.

— - 2003. Axioid shrimps from Guam (Crustacea, Decapoda, Thalassinidea). Micronesica, 35-36: $359-384$.

LIN, F.-J., 2006. Two new axioids (Decapoda: Thalassinidea) from New Caledonia. Journal of Crustacean Biology, 26: 234-241.

Ngoc-Ho, N., 1991. Sur quelques Callianassidae et Upogebiidae de Nouvelle-Calédonie (Crustacea, Thalassinidea). In: B. RICHER DE FORGES (ed.), Le benthos des fonds meubles des lagons de Nouvelle-Calédonie: 281-311, figs. 1-11. (ORSTOM Editions, Paris).

Ortmann, A.E., 1891. Die Decapoden-Krebse des Strassburger Museums mit besonderer Berücksichtigung der von Herrn Dr. Döderlein bei Japan und bei den Liu-Kiu-Inseln gesammelten und z. Z. im Strassburger Museum aufbewahrten Formen. III. Theil. Die Abtheilungen der Reptantia Boas: Homaridae, Loricata und Thalassinidea. Zoologische Jahrbücher, Abteilung für Systematik, 6: 1-58.

Poore, G.C.B., 1994. A phylogeny of the families of Thalassinidea (Crustacea: Decapoda) with keys to the families and genera. Memoirs of the Museum of Victoria, 54: 79-120.

Poore, G.C.B. \& D.J. Collins, 2009. Australian Axiidae (Crustacea: Decapoda: Axiidea). Memoirs of Museum Victoria, 66: 221-287.

Rathbun, M.J., 1906. The Brachyura and Macrura of the Hawaiian Islands. Bulletin of the United States Fisheries Commission, 23: 827-930. pls. 1-24.

Richer DE Forges, B., 1991. Le benthos des fonds meubles des lagons de NouvelleCalédonie: 1-311. (ORSTOM Editions, Paris).

Richer De Forges, B., S.H. Tan, P. Bouchet, P.K.L. NG, T.-Y. Chan \& N. Saguil, 2009. Panglao 2005 - Survey of the deep-water benthic fauna of the Bohol Sea and adjacent waters. Raffles Bulletin of Zoology, (Supplement) 20: 21-38.

SAKAI, K., 1986. Axiopsis brucei sp. nov., a new sponge-inhabiting axiid (Crustacea: Decapoda: Thalassinidea), from north-west Australia. The Beagle, Occasional Papers of the Northern Territory Museum of Arts and Sciences, 3: 11-20.

- —, 1992. Notes on some species of Thalassinidea from French Polynesia (Crustacea: Decapoda). Senckenbergiana Maritima, 22: 211-216.

— —, 1994. Eleven species of Australian Axiidae (Crustacea: Decapoda: Thalassinidea) with descriptions of one new genus and five new species. The Beagle, Occasional Papers of the Northern Territory Museum of Arts and Sciences, 11: 175-202.

SAKai, K. \& M. DE Saint Laurent, 1989. A check list of Axiidae (Decapoda, Crustacea, Thalassinidea, Anomula), with remarks and in addition descriptions of one new subfamily, eleven new genera and two new species. Naturalists, Publications of Tokushima Biological Laboratory, Shikoku University, 3: 1-104.

SAKAI, K. \& S. OHTA, 2005. Some thalassinid collections by R/V "Hakuhou-Maru" and R/V "Tansei-Maru", University of Tokyo, in the Sulu Sea, Philippines, and in Sagami Bay and Suruga Bay, Japan, including two new species, one new genus, and one new family (Decapoda, Thalassinidea). Crustaceana, 78: 67-93.

First received 30 December 2009.

Final version accepted 2 February 2010. 